Agro-Science Journal of Tropical Agriculture, Food, Environment and Extension Volume 17 Number 3 (September 2018) pp. 46-53

ISSN 1119-7455

\title{
DIVERSITY AND SPATIAL DISTRIBUTION OF EPIPHYTIC FLORA ASSOCIATED WITH FOUR TREE SPECIES OF PARTIALLY DISTURBED ECOSYSTEM IN TROPICAL RAINFOREST ZONE
}

\author{
${ }^{1}$ Adubasim C.V., ${ }^{1}$ Akinnibosun H.A., ${ }^{2}$ Dzekewong S.N. and ${ }^{* 2}$ Obalum S.E. \\ ${ }^{1}$ Department of Plant Biology \& Biotechnology, University of Benin, Benin City, Nigeria \\ ${ }^{2}$ Department of Soil Science, University of Nigeria, Nsukka, Nigeria \\ *Corresponding author's email: sunday.obalum@unn.edu.ng; Phone: +234803-968-8755
}

\begin{abstract}
As components of forest communities, epiphytes influence litter and nutrient cycling while providing shelter, nesting materials and food for arboreal animals, thereby promoting diversity. Their preference for certain tree species (phorophytes) influences biodiversity and distribution, but this association is poorly understood in the tropics. We assessed the diversity and spatial distribution of epiphytes associated with four phorophytes (Alstonia booneii, Peltophorum pterocarpum, Mangifera indica and Terminalia catappa) in southern Nigeria, with number of trees sampled as 4, 29, 32 and 44, respectively. The epiphytes were delineated, sampled and identified. Soil samples were collected from tree pockets for textural and $\mathrm{pH}$ analyses. On the four phorophytes, 265 epiphytes under seven species (Platycerium elephantotis, Microgamma owariensis, Nephrolepis biserrata, Funaria hygrometrica, Axonopus compressus, Commelina benghalensis and Ficus spp.) and five families (Polypoidaceae, Funariaceae, Poaceae, Commelinaceae and Moraceae) were recorded. The three most abundant were Funaria hygrometrica (109), Platycerium elephantotis (102) and Microgamma owariensis (44), being present on all four phorophytes. Funaria hygrometrica and Platycerium elephantotis were the most abundant on M. indica (32 each) and T. catappa (44 and 39, respectively). Nephrolepis biserrata appeared only once on T. catappa; so too did Axonopus compressus and Commelina benghalensis on P. pterocarpum. Altogether, A. booneii, P. pterocarpum, M. indica and T. catappa had 11, 62, 89 and 103 epiphytes, respectively. Funaria hygrometrica traversed three tree strata, while others were restricted to two or even one stratum. Canopy layer, middle stratum and lower portion hosted four, five and three epiphytic species, respectively out of the seven recorded, pointing to the relative importance of light, spaciousness and moisture, respectively in epiphyte abundance on trees. Epiphytes distribution on phorophytes was not influenced by texture of the arboreal soils, but was inversely related to their pH. This study has provided useful information on epiphyte-phorophyte association in tropical environments and deserves repetition with more tree species in more natural forests.
\end{abstract}

Key words: forest tree species, tree spatial strata, epiphyte distribution, species abundance, Nigeria

\section{INTRODUCTION}

Epiphytes refer to plants that have true roots but grow on other plants or objects upon which they depend for mechanical support but not for nutrients, thus, they are not parasitic. They derive their nutrients and moisture from air, precipitation, debris and photosynthesis (Benzing, 2008). They are also called aerophytes or air plants. When epiphytes grow on other plants, such supporting plants are called phorophytes. The name epiphyte is coined from the Greek word epi (meaning 'upon') and phyton (meaning 'plant').

As climbing plants, epiphytes live on branches of tall trees and vines where they are able to access sunlight for photosynthesis which plants on lower levels cannot due to dense forest canopy with foliage. Due to adverse environmental conditions, scarcity of resources and eminent competition, epiphytes exhibit ecophysiological, morphological and anatomical adaptations to survive under harsh canopy conditions (Lorenzo et al., 2010). For instance, they have strong yet succulent roots and stems that not only allow them to grow on almost anything, but are extremely efficient in absorbing water from mist, rain and moisture from humidity (Akinsoji, 1990). Species such as bromeliads have stiff, upturned leaves that allow large amounts of water to be stored, while the Staghorn fern (Platycerium madagascariense) has very thick and waxy leaves to retain moisture. Epiphytes produce beautiful and attractive blooms, fruit, perfume and nectar to lure pollinators and produce mass numbers of small seeds that can be transported by wind (Ng and Hew, 2000; Glime, 2007). 
Epiphytic plants play functional roles in forest communities; they influence carbon uptake and biomass production and nutrient cycling as well as provide shelter, nesting materials and food for especially aboreal animals (Ellwood et al., 2002; Bartels and Chen, 2012). Despite their role, this group of plants is understudied compared to their terrestrial counterparts. According to Zotz (2013), there are over 27,614 species of vascular epiphytes worldwide, which is about $9 \%$ of all vascular plant species. Many others have not been identified or catalogued. This situation has been attributed to limited accessibility as well as difficulty in sampling and identification (Kreft et al., 2004; Burns and Zotz, 2010; Zhao et al., 2015). Also, the ecology of many epiphytic species is not well understood especially in the tropics.

Microclimate influences local distribution of vascular epiphytes as vertical stratification of species shows that their occurrence is often restricted to certain microhabitats or microsites (Akinsoji, 1990; Castejon-Silvo and Terrados, 2012). Such stratification is closely related to the vertical variation in ecological factors (biotic and abiotic) found from the forest floor to the canopy (Zhang et al., 2010; Köster et al., 2011). Major factors include phorophyte species, age, shape, size, bark morphology (texture and trunk thickness), branching pattern, height, leaf size, canopy density, moisture retention and chemical composition (Flores-Palacios and Garcia-Franco, 2006; Zhang et al., 2010; Wyse and Burns, 2011; Rosell et al., 2014; Zhao et al., 2015). In Nigeria, the growth of two exotic tree species was reported to depend on physicochemical properties of a plantation forest soil (Watanabe et al., 2009), just as the distribution of weed species follows local differences in soils (Udoh et al., 2007). The extent to which this kind of association could hold true between epiphytic species and arboreal soils captured and retained in hollows of supporting tree species is not clear.

This study was, therefore, carried out in Benin in southern Nigeria, typifying a tropical rainforest zone. The objectives were to (i) identify epiphytic species associated with selected tree species, (ii) establish their relative abundance and distribution on the trees, and (iii) relate such distribution to soil texture and $\mathrm{pH}$ of arboreal soils on the tree species.

\section{MATERIALS AND METHODS \\ Study Area}

The study was carried out at the University of Benin, Ugbowo Campus, in southern part of Edo State, Nigeria between Nov. 2015 and Feb. 2016. The area is situated at $06^{\circ} 23^{\prime} \mathrm{N}$ and $005^{\circ} 37^{\prime} \mathrm{E}$, and is on elevation of $96-130 \mathrm{~m}$ asl. It has a humid tropical climate and lies within a heavy rainfall zone with two distinct seasons; the dry season between Oct. and Jan. and the rainy season that is usually from Feb. to Sep., having two rainfall peaks in Jun. and Sep. There is a short dry period around Aug. commonly referred to as the "August break". The range of annual rainfall is $1500-2500 \mathrm{~mm}$. The area experiences marked variations in diurnal temperature throughout the year. There are two temperature ranges; the high range that occurs during the four dry months and the low range in the eight months of rainfall due to the cooling effect of the rain. Relative humidity is usually lowest in Dec. and Jan. which are the peaks of the dry season.

The soil type here is the low-fertility coarsetextured soil. The vegetation is mainly rainforest with areas of secondary growth (Okhakhu, 2016). The site for the present study represents a partially disturbed ecosystem in this tropical rainforest zone in that, being a university campus housing the Faculty of Agriculture among other faculties, many trees have been felled such that the original tree contiguity has been apparently interfered with but not epiphyte growth on the remaining trees.

\section{Sampling and Data Collection}

The study utilised four tree species; Alstonia boonei (God's tree), Peltophorum pterocarpum (yellow flametree), Mangifera indica (mango tree) and Terminalia catappa (tropical-almond) selected using the random method of sampling. Alstonia boonei de Wild is a very large, deciduous, tropical forest tree in the dogbane family of Apocynaceae. The tree is native to West Africa. Peltophorum pterocarpum (D.C.) K. Heyne is a deciduous ornamental tree growing to $15-25 \mathrm{~m}$ and rarely up to $50 \mathrm{~m}$ tall, with a trunk of up to $1 \mathrm{~m}$ wide. It belongs to family Fabaceae/Leguminosae. It is native to tropical Southeast Asia. Mangifera indica Linn., commonly called mango, is a species of flowering plants in the Anacardiaceae family. The tree is erect, 9-30 m high, with a broad, rounded canopy which, with age, attains $30-38 \mathrm{~m}$ wide or a more upright, oval, fairly slender crown. It is native to India. Terminalia catappa Linn. is a large tropical tree in the leadwood tree family, Combretaceae. It grows to $35 \mathrm{~m}$ tall, with an upright, symmetrical crown and horizontal branches. Besides serving as an ornamental and shade tree, the tree produces corky light edible fruits dispersed by water.

A quadrat of $900 \mathrm{~cm}^{2}$ was used to mark out an area round each tree for sampling. Synthetic characters assessed of the epiphytic species were presence and occurrence. Presence was inferred from visual observation. Occurrence, the degree of presence of a given species in the sampled trees, was calculated as the percentage ratio of the number of trees on which the epiphyte appeared to the total number of trees sampled.

Analytical characters estimated for each epiphytic species were cover, density and frequency. To do the estimation, the quadrat was placed on various parts of the trees. Cover was estimated as the area of the quadrat covered by 
individual epiphytes. The cover was then evaluated by the Dansereau's (1951) coverage scale, whereby $5,4,3,2,1$ and + represent 100-75, 75-50, 50-25, $25-5,5-1$ and $<1 \%$ coverage, respectively. Density was estimated as the number of individual epiphytic species per unit sampled area. Frequency was estimated as the fraction of sampled area containing the given species. The proportional representation of each epiphytic species among all species on a phorophyte was determined as relative cover/density/frequency (Gradstein et al., 2003):

$$
\begin{aligned}
& \text { Relative cover or relative density } \\
& \text { or relative frequency }=\frac{x}{y} \times 100 \% \text {; }
\end{aligned}
$$

where $x$ is cover, density or frequency for an epiphytic species and $y$ is the sum of corresponding parameter for all species on a phorophyte. For each tree species data collected from all quadrats on these analytical characters were averaged.

Two qualitative characters, those based on some permanent features and not according to spatial importance within the quadrat, including sociability and stratification/layering, were assessed of the epiphytic species. Sociability was graded 5, 4, 3, 2 and 1 for plants growing in thick or large colonies, plants growing in thin or small colonies, plants that are few or sparsely populated, plants growing in two groups or turfs, and plants growing as isolated individuals, respectively. For stratification/layering, the quadrats were carefully examined for superimposition or overlapping of the epiphytic flora in strata or layers. These layers were then graded accordingly on a scale of L-1 to L-4; with L-1, L-2, L-3 and L-4 representing basal stratum, lower portion, middle layer, and top layer (canopy) of the tree, respectively.

To identify the epiphytes, those at the base and trunk level were collected after close observation, while those at the canopy layer were collected with the aid of an adjustable ladder. Some of the epiphytes were identified in-situ using the works of Hutchison and Dalziel (1972) and Aigbokhan (2014). Others that could not be identified in the field were pressed and deposited at the herbarium of the University of Benin for identification. Also, soil samples were collected from the pockets of sampled phorophytes. These arboreal soil samples were taken to the laboratory and analysed for particle size distribution and soil $\mathrm{pH}$.

\section{RESULTS AND DISCUSSION}

A total of 265 epiphytes were recorded on the four 'host' tree species (phorophytes) selected including Alstonia booneii, Peltophorum pterocarpum, Mangifera indica and Terminalia catappa. The 265 epiphytes belong to seven epiphytic species which in turn belong to five families. The epiphytic species included Platycerium elephantotis (elephant ear staghorn), Microgamma owariensis (snakeferns) and Nephrolepis biserrata (giant sword fern) which are all pteridophytes in the Polypoidaceae family. Other epiphytic species were Funaria hygrometrica (bonfire moss), Axonopus compressus (carpet grass), Commelina benghalensis (dayflower) and Ficus spp. (figs) in the Funariaceae, Poaceae, Commelinaceae and Moraceae families, respectively. Microgamma owariensis is believed to originate from West Africa. Funaria hygrometrica, the most abundant moss currently recognised in the southern part of Africa, is a bryophyte. Both Axonopus compressus and Commelina benghalensis are monocotyledonous angiosperms. Ficus spp. is a dicotyledonous angiosperm that is native throughout the tropics.

The most abundant epiphytic species was Funaria hygrometrica, followed by Platycerium elephantotis and Microgamma owariensis (Table 1). These three species were not selective as they were found on all four phorophytes studied (Plates 1-4). Notably, Funaria hygrometrica was present in every sampled tree. The distribution of epiphytic species on the phorophytes was uneven, and this is attributed to differences in traits of the epiphytes and phorophytes alike and to microclimatic variations (Brown, 1990; Mezaka et al., 2012). For instance, Platycerium elephantotis and Funaria hygrometrica were observed growing in clusters. Platycerium elephantotis is highly diverse and variable between individual plants (Desalegn and Lekelefac, 2005), and together with Funaria hygrometrica, requires little soil and shady, humid environments that favour reproduction by spores (Mucunguzi, 2007), hence their abundance and presence in all the four phorophytes. Also, Mucunguzi (2007) recorded high occurrence of epiphytic species in the family of Polypoidaceae. This is the family to which Platycerium elephantotis and Microgamma owariensis found to be among the abundant species in the present study belong. It could be, therefore, that species in this family are ubiquitous.

\begin{tabular}{|c|c|c|c|c|c|c|c|c|c|c|c|c|c|c|c|c|}
\hline \multirow[t]{2}{*}{ Tree species } & \multirow[t]{2}{*}{$\begin{array}{c}\text { No. of trees } \\
\text { sampled }\end{array}$} & \multicolumn{2}{|c|}{$\begin{array}{l}\text { Platycerium } \\
\text { elephantotis }\end{array}$} & \multicolumn{2}{|c|}{$\begin{array}{c}\text { Microgamma } \\
\text { owariensis }\end{array}$} & \multicolumn{2}{|c|}{$\begin{array}{c}\text { Nephrolepis } \\
\text { biserrata }\end{array}$} & \multicolumn{2}{|c|}{$\begin{array}{c}\text { Funaria } \\
\text { hygrometrica }\end{array}$} & \multicolumn{2}{|c|}{$\begin{array}{c}\text { Axonopus } \\
\text { compressus }\end{array}$} & \multicolumn{2}{|c|}{$\begin{array}{c}\text { Commelina } \\
\text { benghalensis }\end{array}$} & \multicolumn{2}{|c|}{$\begin{array}{l}\text { Ficus } \\
\text { spp. }\end{array}$} & \multirow[t]{2}{*}{$\begin{array}{l}\text { Total No. of } \\
\text { epiphytes }\end{array}$} \\
\hline & & PRS & OCC & PRS & OCC & PRS & OCC & PRS & OCC & PRS & OCC & PRS & OCC & PRS & OCC & \\
\hline $\begin{array}{l}\text { Alstonia } \\
\text { booneii } \\
\text { Peltophor }\end{array}$ & 4 & 4 & 100.00 & 3 & 75.00 & 0 & 0.00 & 4 & 100.00 & 0 & 0.00 & 0 & 0.00 & 0 & 0.00 & 11 \\
\hline $\begin{array}{l}\text { Peltophorum } \\
\text { pterocarpum } \\
\text { Mangifera }\end{array}$ & 29 & 27 & 86.21 & 4 & 13.79 & 0 & 0.00 & 29 & 100.00 & 1 & 3.45 & 1 & 3.45 & 0 & 0.00 & 52 \\
\hline $\begin{array}{l}\text { indica } \\
\text { Terminalia }\end{array}$ & 32 & 32 & 100.00 & 25 & 78.13 & 0 & 0.00 & 32 & 100.00 & 0 & 0.00 & 0 & 0.00 & 0 & 0.00 & 89 \\
\hline $\begin{array}{l}\text { catappa } \\
\text { Total No. of } \\
\text { epiphytes }\end{array}$ & 44 & 102 & 88.64 & 12 & 27.27 & 1 & 2.27 & 109 & 100.00 & 2 & 4.55 & 2 & 4.55 & 3 & 6.82 & 103 \\
\hline epiphytes & & 102 & & 44 & & 1 & & 109 & & 3 & & 3 & & 3 & & 265 \\
\hline
\end{tabular}

Table 1: Summary of the epiphyte abundance as indexed by presence (PRS) and percent occurrence (OCC) on the four tree species 


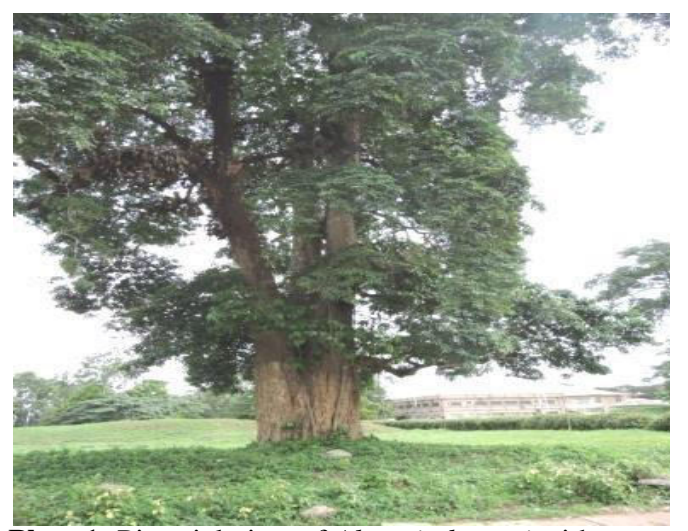

Plate 1: Pictorial view of Alstonia boonei with epiphytes associated with it at the study site

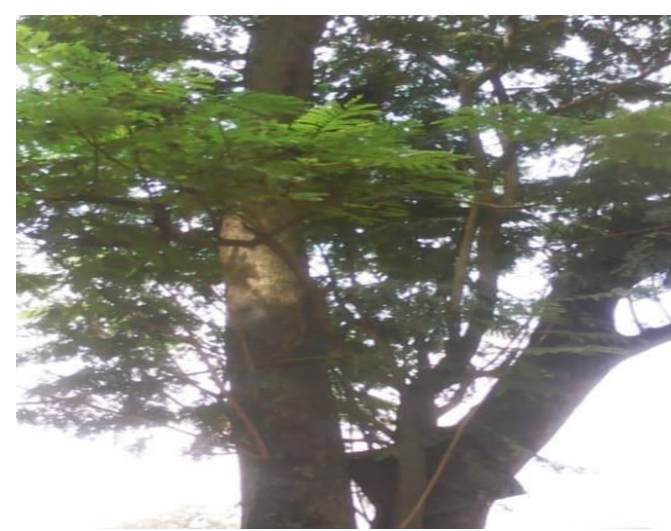

Plate 2: Pictorial view of Peltophorum pterocarpum with epiphytes associated with it at the study site

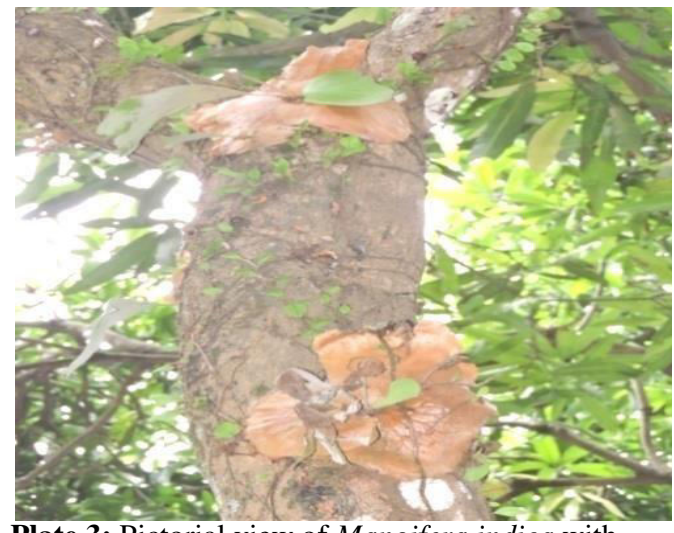

Plate 3: Pictorial view of Mangifera indica with epiphytes associated with it at the study site

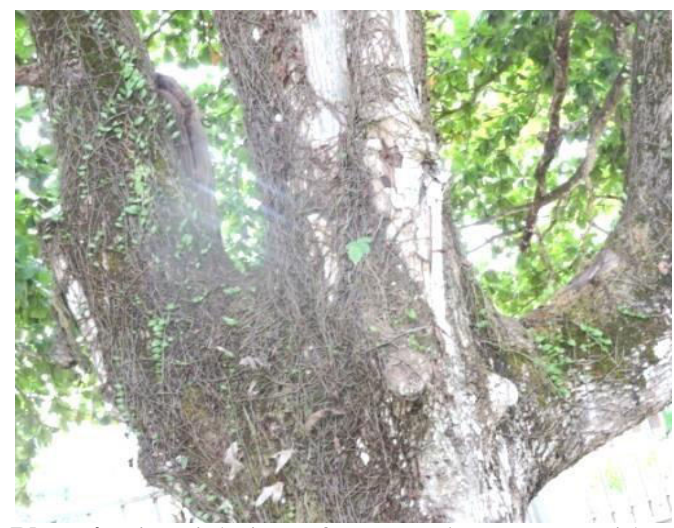

Plate 4: Pictorial view of Terminalia catappa with epiphytes associated with it at the study site
For the phorophytes, the one with the lowest number of epiphytes was Alstonia booneii (11), followed by Peltophorum pterocarpum (62). Alstonia booneii produces white latex which may explain the poor diversity of epiphytes on it. Peltophorum pterocarpum with the second lowest number has a dense and spreading crown, but a smooth bark which does not support epiphyte establishment (Akinsoji, 1990). The remaining two tree species, Mangifera indica and Terminalia catappa, with higher number of epiphytes have features such as rough bark, tall height, large trunk and large canopy that support abundance and high occurrence of epiphytes (Akinsoji, 1990; Andama et al., 2003; Oloyede et al., 2014; Zhao et al., 2015).

The epiphytic species Funaria hygrometrica and Platycerium elephantotis appeared the most per stand not only on Mangifera indica (32 each), but also on Terminalia catappa (44 and 39, respectively). By contrast, Axonopus compressus, Commelina benghalensis and Nephrolepis biserrata appeared the least at the study site, as each of these epiphytic species was found just once on Peltophorum pterocarpum, Peltophorum pterocarpum and Nephrolepis biserrata, respectively. The observation for Nephrolepis biserrata is rather contrary to Oloyede et al. (2014) who reported it as one of the most common species in Obafemi Awolowo University Estate in southwestern Nigeria. According to this author, Nephrolepis biserrata is host-specific and is associated with Elaeis guineensis (palm tree) whose characteristics are different from those of the tree species of the present study.

Mean analytical characters of the epiphytic species found on each of the four phorophytes are shown (Table 2). Microgamma owariensis generally showed the highest values for cover, density and frequency; the only exceptions to this trend were for cover and frequency on Mangifera indica and Terminalia catappa where Funaria hygrometrica showed the highest values. Values of relative cover, relative density and relative frequency generally increased with a decrease in number of observations, $n$, made of the epiphytes on a given phorophyte which, in this study, represents presence of the epiphytic species on the said phorophyte.

Further, anthropogenic activities such as clearing of under-storey, pruning of tree branches or felling of whole trees often take place at the study site. These activities which alter the natural environment and disturb the natural habitat play a major role in changing the diversity and distribution of vascular epiphytes, and so may have influenced the data attained (Flores-Palacios and Garcia-Franco, 2004; Hietz et al., 2006; Kromer and Gradstein, 2007). Such activities lead to species isolation, reduced cover, increased exposure to solar radiation and associated increase in evapotranspiration rate, all of which modify the microclimate. 
Table 2: Mean analytic characters of epiphytes on selected tree species

\begin{tabular}{|c|c|c|c|c|c|c|c|}
\hline Tree Species & Epiphytic Species & $\begin{array}{c}\text { Species } \\
\text { cover }\end{array}$ & $\begin{array}{c}\text { Relative } \\
\text { cover }\end{array}$ & $\begin{array}{l}\text { Species } \\
\text { density }\end{array}$ & $\begin{array}{c}\text { Relative } \\
\text { density }\end{array}$ & $\begin{array}{c}\text { Species } \\
\text { frequency }\end{array}$ & $\begin{array}{l}\text { Relative } \\
\text { frequency }\end{array}$ \\
\hline \multirow[t]{3}{*}{ Alstonia booneii } & Platycerium elephantotis $(n=4)$ & 4.00 & 25.00 & 0.003 & 25.00 & 0.67 & 25.00 \\
\hline & Microgamma owariensis $(n=3)$ & 5.00 & 33.30 & 0.021 & 33.33 & 0.83 & 33.33 \\
\hline & Funaria hygrometrica $(n=4)$ & 4.00 & 25.00 & 0.014 & 25.00 & 0.67 & 25.00 \\
\hline \multirow[t]{5}{*}{ Peltophorum pterocarpum } & Platycerium elephantotis $(n=27)$ & 3.41 & 3.70 & 0.005 & 3.70 & 0.57 & 3.71 \\
\hline & Microgamma owariensis $(n=4)$ & 4.50 & 25.00 & 0.030 & 25.00 & 0.75 & 25.00 \\
\hline & Funaria hygrometrica $(n=29)$ & 3.48 & 3.45 & 0.015 & 3.45 & 0.58 & 3.46 \\
\hline & Axonopus compressus $(n=1)$ & 1.00 & 100.00 & 0.001 & 100.00 & 0.17 & 100.00 \\
\hline & Commelina benghalensis $(n=1)$ & 1.00 & 100.00 & 0.001 & 100.00 & 0.07 & 100.00 \\
\hline \multirow[t]{3}{*}{ Mangifera indica } & Platycerium elephantotis $(n=32)$ & 3.06 & 3.13 & 0.004 & 3.13 & 0.51 & 3.13 \\
\hline & Microgamma owariensis $(n=25)$ & 2.72 & 4.00 & 0.011 & 4.00 & 0.45 & 4.01 \\
\hline & Funaria hygrometrica $(n=32)$ & 3.78 & 3.13 & 0.009 & 3.13 & 0.63 & 3.12 \\
\hline \multirow[t]{7}{*}{ Terminalia catappa } & Platycerium elephantotis $(n=39)$ & 2.67 & 2.56 & 0.002 & 1.89 & 0.44 & 2.56 \\
\hline & Microgamma owariensis $(n=12)$ & 2.92 & 8.33 & 0.009 & 8.33 & 0.49 & 8.33 \\
\hline & Nephrolepis biserrata $(n=1)$ & 1.00 & 100.00 & 0.001 & 100.00 & 0.17 & 100.00 \\
\hline & Funaria hygrometrica $(n=44)$ & 3.57 & 2.27 & 0.009 & 2.27 & 0.60 & 2.27 \\
\hline & Axonopus compressus $(n=2)$ & ND & ND & ND & ND & ND & ND \\
\hline & Commelina benghalensis $(n=2)$ & ND & ND & ND & ND & ND & ND \\
\hline & Ficus spp. $(n=3)$ & 1.00 & 33.33 & 0.001 & 33.33 & 0.17 & 33.33 \\
\hline
\end{tabular}

$\overline{\mathrm{ND}}$, Not determined

The epiphytes exhibited sociability (Table 3). Also, the middle stratum (sub-canopy level) registered the highest number of epiphytic species, 5 out of 7 (Table 3). Kersten et al. (2009) and Zhao et al. (2015) made similar observations in coastal Atlantic rainforest at Ilha do Mel Island of Brazil and tropical montane forest in SW China, respectively. In the present study, the middle stratum was followed by the canopy layer with four species and the lower portion with three species; just as an examination of the quadrats for superimposition showed a certain level of stratification (Table 3). Two species were found at the lower portion and only one species at the basal stratum. This observation could be due to limited amount of light reaching the base of the phorophytes. Funaria hygrometrica was identified in three tree strata; Platycerium elephantotis, Microgamma owariensis and Axonopus compressus were found in two strata; while Nephrolepis biserrata, Commelina benghalensis and Ficus spp. were restricted to one stratum being L-4, L-1 and L-3, respectively.

Overall, the data in Table 3 show that most of the epiphytic species preferred the last two layers upwards (middle layer and top layer or canopy of the tree) to the first two layers upwards (basal stratum and lower portion). These results suggest that light availability and intensity are major factors in epiphyte location within the microhabitat. Similar results have been reported by Akinsoji (1990), Oloyede et al. (2014) and Zhao et al. (2015). According to Richter (1991), epiphytes are very sensitive to direct solar radiation and changes in climatic conditions. However, such radiation is often not possible as leaves on tree canopy cast shade on the trunk while allowing light to penetrate. This situation modifies the entire environment of the tree and specifically the microclimate of the trunk where the epiphytes grow. Many epiphytic species occur at the intermediate canopy of trees due not only to large surface area and substrate found on the main forks or axils, but also to the intermediate light and moisture (Flores-Palacios and Garcia-Franco, 2006; Krömer et al., 2007; Köster et al.,, 2011; Zhao et al., 2015). Occurrence at the basal stratum and lower portion could be an adaptation strategy to minimize water loss via evapotranspiration, and this explains the uneven distribution and composition of epiphytic species across the different strata on the phorophytes.

Table 3: Sociability and layering of the epiphytes on the sampled trees

\begin{tabular}{lll}
\hline Taxa & Sociability & Layering \\
\hline Platycerium elephantotis & SOC 5 & L-3, L-4 \\
Microgamma owariensis & SOC 4 & L-3, L-4. \\
Nephrolepis biserrata & SOC 1 & L-4 \\
Funaria hygrometrica & SOC 5 & L-2, L-3, L-4 \\
Axonopus compressus & SOC 1 & L-2, L-3 \\
Commelina benghalensis & SOC 1 & L-1 \\
Ficus spp. & SOC 1 & L-3
\end{tabular}

$\overline{\text { SOC - Sociability, L - Layering; SOC 5, 4, 3, } 2 \text { and } 1 \text { represent }}$ plants growing in thick or large colonies, plants growing in thin or small colonies, plants that are few or sparsely populated, plants growing in two groups or turfs, and plants growing as isolated individuals, respectively; L-1, L-2, L-3 and L-4 represent basal stratum, lower portion, middle layer, and top layer (canopy) of the tree, respectively 
The soils collected from the pockets of the four phorophytes all had well above $90 \%$ sand (Figure 1); hence they are not just sandy but belong specifically to the textural class of sand. This sandiness of the arboreal soil could be reflecting loss of fine particles to regular washing by rainfall, throughfall and post-rain trunk-dripping water. Sand is chemically inert and so contributes little or nothing to both water retention and cation exchange in highly weathered tropical soils (Obalum and Obi, 2013; Obalum et al., 2013). With this situation, therefore, the soil component of the microhabitats provided by the phorophytes would be expected to be of low water holding capacity and fertility status, implying that water and nutrients due to it were not sufficient to support the epiphytes. For their nutrition, the epiphytes must rely more on rainfall/throughfall and litterfall as well as materials brought by wind and animals.

Availability and physico-chemical properties of substrates vary among environments and tree species (Cardelús et al., 2007), such that adaptation of epiphytic species is also a factor. For instance, under harsh environmental conditions, many of Platycerium elephantotis are adapted to store water in their leaves and to root with little substrate (Mucunguzi, 2007). Therefore, the abundance of this species in the present study is not surprising.

The $\mathrm{pH}$ of the soils in all investigated microhabitats is shown (Figure 2). The results show that the arboreal soils were generally acidic. Gill and Onyibe (1986) obtained similar results in their phytosociological studies of epiphytic flora on Elaeis guineensis. The highest $\mathrm{pH}$ of 6.5 was obtained for the soils collected on Alstonia booneii, the tree species with 11 epiphytes, which was the lowest number of epiphytes recorded in this study. Intermediate $\mathrm{pH}$ values of 5.5 were obtained for the soil samples collected on Peltophorum pterocarpum

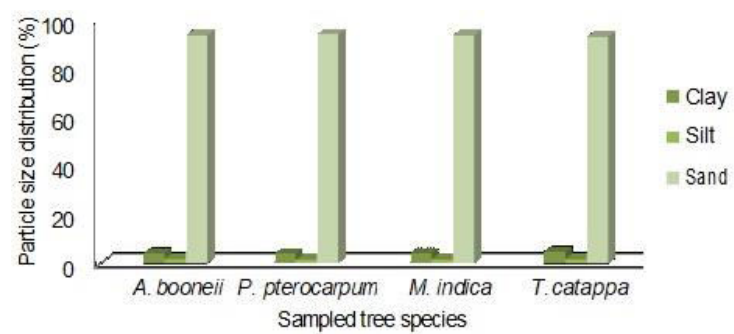

Figure 1: Particle size distribution of the arboreal soils collected from hollows in the four sampled tree species

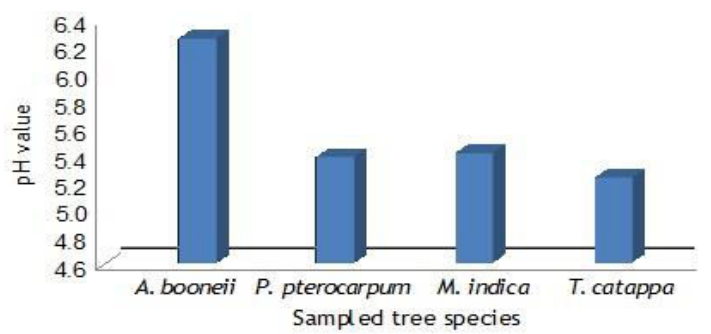

Figure 2: Soil $\mathrm{pH}$ values of the arboreal soils collected from hollows in the four sampled tree species and Mangifera indica, with 62 and 89 epiphytes, respectively. Further, the lowest $\mathrm{pH}$ of 5.0 was obtained for the soils collected on Terminalia catappa with the overall highest number of epiphytes of 103. This trend suggests that epiphytes prefer acid environments to near-neutral ones.

Based on the above observations, it could be inferred that the $\mathrm{pH}$ of arboreal soils inversely related with epiphyte distribution, with a high correlation coefficient, $r$, of -0.83 . These results not only contradict the notion that soil $\mathrm{pH}$ is not a factor in epiphyte distribution and abundance (Pessin, 1925), but also challenge the notion that host effect is modulated by nutrient inputs from the atmosphere (Flores-Palacios and Garcia-Franco, 2004). As opined by Callaway et al. (2002) and Hsu et al. (2006), changes in microclimatic factors in the environment and some specific species adaptation/tolerance traits influence epiphyte distribution and abundance. The present results show the underlying role of the $\mathrm{pH}$ of soils adhering to phorophytes in such changes and adaptation/tolerance in tropical environments.

One perceived shortcoming of the data reported here is that the study was executed with only four tree species in a campus environment where the forest ecology had been partially disturbed, with the trees mostly isolated from one another. Since the population of epiphytes is typically higher in natural than disturbed forests (Andama et al., 2003), our data need validation through more robust studies involving more tree species that could offer even wider contrasts of phorophytic features in natural forests of representative tropical ecosystems.

\section{CONCLUSIONS}

The study has identified seven epiphytic species that could thrive on such trees as Alstonia booneii, Peltophorum pterocarpum, Mangifera indica and Terminalia catappa in humid tropical environments. These species include Platycerium elephantotis, Microgamma owariensis and Nephrolepis biserrata all in the family of Polypoidaceae as well as Funaria hygrometrica, Axonopus compressus, Commelina benghalensis and Ficus spp. in the Funariaceae, Poaceae, Commelinaceae and Moraceae families, respectively. Abundance and distribution of Funaria hygrometrica was spectacular, as it was found on all four tree species, traversing three strata. Platycerium elephantotis and Microgamma owariensis were the next two most abundant and widely distributed species on these trees, but not without showing preference for the middle and canopy layers. It seems that the number of epiphytes to be found on a given 'host' tree species linearly varies with the latter's size (tree height, trunk size and canopy cover). Also, epiphyte distribution on trees does not depend on texture of the soils in their pockets; instead, it depends on $\mathrm{pH}$ of such arboreal soils, with wider distribution as their $\mathrm{pH}$ tends towards acidity. 
In our perception, the carrying out of this study with only four tree species in a partially disturbed ecosystem where some of the phorophytes were found in isolation such that tree-canopy cross-cover effects were apparently lacking poses a limitation to the conclusions and inferences drawn. The study, nevertheless, has contributed to our understanding of the association of epiphytes with forest trees in tropical environments. A repeat of the study with more tree species in natural forest environments is, however, needed to add to our understanding of the observations made and interpretation of same.

\section{REFERENCES}

Aigbokhan E.I. (2014). Annotated Checklist of Vascular Plants of Southern Nigeria - A Quick Reference Guide to the Vascular Plants of Southern Nigeria: A Systematic Approach. UniBen Press, Benin City, $346 \mathrm{pp}$.

Akinsoji A. (1990). Studies on epiphytic flora of a tropical rainforest in South-western Nigeria, I: the vascular epiphytes. Vegatatio, 88 (1), 87-92

Andama E., Michira C.M. and Luilo G.B. (2003). Studies on epiphytic ferns as potential indicators of forest disturbances. Paper submitted to the XII World Forestry Congress 2003, Quebec City, Canada

Bartels S.F. and Chen H.H. (2012). Mechanisms regulating epiphytic plant diversity. Critical Reviews in Plant Sciences, 31 (5), 391-400

Benzing D.H. (2008). Vascular Epiphytes: General Biology and Related Biota. Cambridge University Press, $376 \mathrm{pp}$.

Brown D.A. (1990). El epifitismo en las selvas montanas del Parque Nacional "El Rey" Argentina: Composición florística y padrón de distribución. Revista de Biología Tropical, 38, 155-166

Burns K.C and Zotz G. (2010). A hierarchical framework for investigating epiphyte assemblages: networks, meta-communities, and scale. Ecology, 91, 377-385

Callaway R.M., Reinhart K.O., Moore O.J. and Pennings S.C. (2002). Epiphyte host preferences and host traits: mechanisms for species-specific interactions. Oecologia, 132, 221-230

Cardelús C.L. (2007). Vascular epiphyte communities in the inner-crown of Hyeronima alchorneoides and Lecythisampla at La Selva Biological Station, Costa Rica. Biotropica, 39, 171-176

Castejon-Silvo J. and Terrados J. (2012). Patterns of spatial variation of nutrient content, epiphytic load and shoot size of Posidonia oceanica. Marine Ecology, 33 (2), 165-175

Dansereau P. (1951). Description and recording of vegetation upon a structural basis. Ecology, 32, $172-229$

Desalegn C. and Lekelefac M. (2005). Host preference by Platycerium elephantotis Scheinf. (Polipodiaceae): a case study in Kibale National Park, western Uganda. TBA Field Course Project Reports 05/1

Ellwood M.D.F., Jones D.T. and Foster W.A. (2002). Canopy ferns in lowland dipterocarp forest support a prolific abundance of ants, termites and other invertebrates. Biotropica, 34, 575-583

Gill L.S. and Onyibe I.H. (1986). Phytosociological studies of the epiphytic flora of oil palm (Elaeis guineensis) in Benin City, Nigeria. Feddes Repertorium, 11 (12), 691-695
Glime J.M. (2007). Bryophyte Ecology, Vol. 1 Physiological Ecology. Michigan Technological University, Botanical Society of America and the International Association of Bryologists. Available at: http://www.bryoecol.mtu.edu

Gradstein S.R., Nadkarni N.M., Kromer T., Holz I. and Noske N. (2003). A protocol for rapid and representative sampling of vascular and nonvascular epiphyte diversity of tropical rain forests. Selbyana, 24, 190-195

Hietz P., Buchberger G. and Winkler M. (2006). Effect of forest disturbance on abundance and distribution of epiphytic bromeliads and orchids. Ecotropica, 12, 103-112

Hsu C.C., Lin T.C., Chiou W.L., Lin S.H., Lin K.C. and Martin C.E. (2006). Canopy $\mathrm{CO}_{2}$ concentrations and crassulacean acids metabolism in Hoya carnosa in a subtropical rainforest in Taiwan: consideration of $\mathrm{CO}_{2}$ availability and the evolution of CAM in epiphytes. Photosynthetica, 44, 130-135

Hutchinson J. and Dalziel J.M. (1972). Flora of West Tropical Africa, $2^{\text {nd }}$ ed. Revised by Keay R.W.J. and edited by Hepper F.N. Published on behalf of the Governments of Nigeria, The Gold Coast, Sierra Leone and The Gambia by the Crown Agents for Oversea Governments and Administrations, Millbank, London

Kersten R.A., Borgo M. and Silva S.M. (2009). Diversity and distribution of vascular epiphytes in an insular Brazilian coastal forest. Revista de Biología Tropical, 57 (3), 749-759

Köster N., Nieder J. and Barthlott W. (2011). Effect of host tree traits on epiphyte diversity in natural and anthropogenic habitats in Ecuador. Biotropica, 43, 685-694

Kreft H., Koster N., Kuper W., Nieder J. and Barthlott W. (2004). Diversity and biogeography of vascular epiphytes in Western Amazonia, Yasuni, Ecuador. Journal of Biogeography, 31 (9), 1463-1476

Krömer T., Kessler M. and Gradstein S.R. (2007). Vertical stratification of vascular epiphytes in submontane and montane forest of the bolivian andes: the importance of the understorey. Plant Ecology, 189, 261-278

Lorenzo N., Mantuano D.G. and Mantovani A. (2010). Comparative leaf ecophysiology and anatomy of seedlings, young and adult individuals of the epiphytic aroid Anthurium scandens (Aubl) Engl. Environmental \& Experimental Botany, 68, 314-322

Mezaka A., Brumelis G. and Piteräns A. (2012). Tree and stand-scale factors affecting richness and composition of epiphytic bryophytes and lichens in deciduous woodland key habitats. Biodiversity \& Conservation, 21 (12), 3221-3241

Mucunguz P. (2007). Diversity and distribution of epiphytic ferns in Kibale National Park, Uganda. Selbyana, 28 (2), 154-160

Ng C.K.Y. and Hew C.S. (2000). Orchid pseudo bulbs 'false' bulbs with a genuine importance in orchid growth and survival! Scientia Horticulturae, 83, $165-172$

Obalum S.E. and Obi M.E. (2013). Moisture characteristics and their point pedotransfer functions for coarsetextured tropical soils differing in structural degradation status. Hydrological Processes, 27 (19), 2731-2735 
Obalum S.E., Watanabe Y., Igwe C.A., Obi M.E. and Wakatsuki T. (2013). Improving on the prediction of cation exchange capacity for highly weathered and structurally contrasting tropical soils from their fine-earth fractions. Communications in Soil Science \& Plant Analysis, 44 (12), 1831-1848

Okhakhu P.A. (2016). Assessment of the urban climate of Benin City, Nigeria. Journal of Environment \& Earth Science, 6 (1), 2225-0948

Oloyede F.A., Odiwe A.I. and Olujiyan A.S. (2014). Composition and distribution of vascular epiphytes in different areas in Obafemi Awolowo, Nigeria. Notulae Scientia Biologicae, 6 (3), 316-320

Pessin L.J. (1925). An ecological study of the polypody fern Polypodium polypodioides as an epiphyte in Mississippi. Ecology, 6, 17-38

Richter F.T. (1991). Methoden der Klimaindikation durch pflanzenmorphologische Merkmale in den Kordilleren der Neotropis. Die Erde, 122 (4), 267-289

Rosell J.A., Gleason S., Méndez-Alonzo R., Chang Y. and Westoby M. (2014). Bark functional ecology: evidence for tradeoffs, functional coordination, and environment producing bark diversity. New Phytologist, 201, 486-497
Udoh B.T., Ogunkunle A.O. and Ndaeyo N.U. (2007). Influence of soil series and physico-chemical properties on weed flora distribution and at Moor Plantation Ibadan, southwestern Nigeria. Journal of Agriculture \& Social Sciences, 3 (2), 55-58

Watanabe Y., Masunaga T., Fashola O.O., Agboola A., Ovisuyi P.K. and Wakatsuki T. (2011). Eucalyptus camaldulensis and Pinus caribaea growth in relation to soil physico-chemical properties in plantation forests in Northern Nigeria. Soil Science \& Plant Nutrition, 55, 132-141

Wyse S.V. and Burns B.R. (2011). Do host bark traits influence trunk epiphyte communities. Journal of Ecology, 35 (3), 296-301

Zhang L., Nurvianto S. and Harrison R. (2010). Factors affecting the distribution and abundance of Asplenium nidus L. in a tropical lowland rain forest in Peninsular Malaysia. Biotropica, 42, 464- 469

Zhao M., Geekiyanage N., Xu J., Khin M.M., Nurdiana D.R., Paudel E. and Harrison R.D. (2015). Structure of the epiphyte community in a tropical montane forest in SW China. PLOS ONE, 10 (4): e0122210. https://doi.org/10.1371/journal.pone.0122210

Zotz G. (2013). The systematic distribution of vascular epiphytes - a critical update. Botanical Journal of the Linnean Society, 171, 453-481 